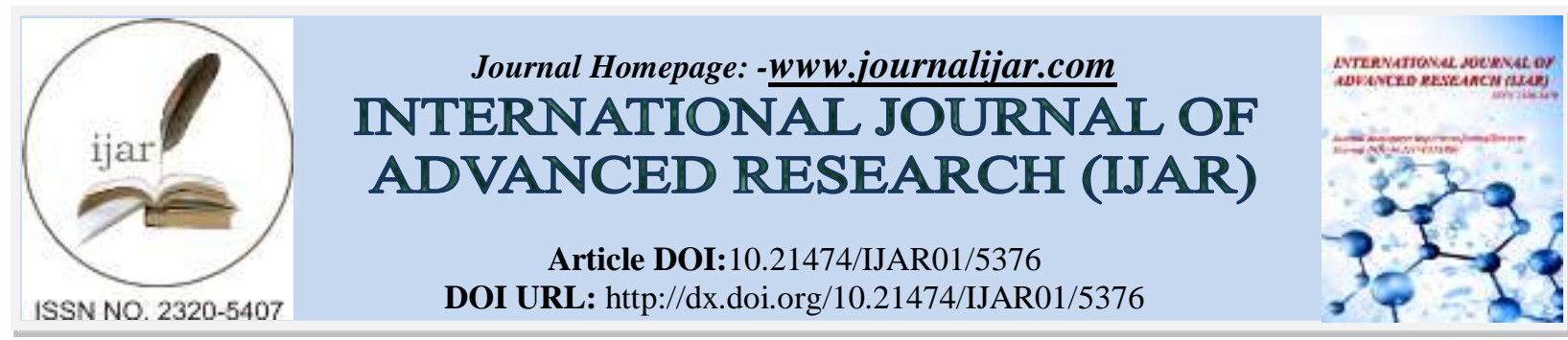

RESEARCH ARTICLE

\title{
DECOLORIZATION OF DARK RED 2B AZO DYE BY SPHINGOMONAS PAUCIMOBILIS ISOLATED FROM TEXTILE EFFLUENT.
}

\begin{abstract}
Alkesh I. Shah ${ }^{1}$ and Jaydip B. Jobanputra ${ }^{2}$.
1. Associate Professor \& Head, Zoology Department, B. P. Baria Science Institute, Navsari - 396445, India.

2. Biotechnology Department, Bhagwan Mahavir College of Science \& Technology, Near VIP Road, Vesu, Surat.
\end{abstract}

\section{Manuscript Info}

Manuscript History

Received: 09 July 2017

Final Accepted: 11 August 2017

Published: September 2017

Key words:-

Azo dyes, Bacterial decolorization, Dark

Red 2B, Phytotoxicity,

Sphingomonaspaucimobilis.

\begin{abstract}
Synthetic azo dyes, present in textile effluent, are chemically Synthetic azo dyes found in textile effluent are chemically stable and persist in environment if discharged untreated. They cause many environmental issues and are toxic to aquatic life as well as carcinogenic and mutagenic to humans. There exist many physico-chemical methods for the removal of dyestuff form textile effluent, but all are having some disadvantages. Use of microorganisms for decolorization and degradation of such azo dyes in textile effluent is one of the thrust area of research. Many bacterial strains have been shown to degrade and mineralize azo dyes in waste water. In this study, indigenous bacterial strains were isolated from textile effluent capable for decolorization of Dark Red 2B azo dye. Sphingomonas paucimobilis, was isolated showing highest capacity of dye decolorization of $98.46 \%$ among 16 isolates obtained after screening. The optimum temperature and $\mathrm{pH}$ for dye decolorization was found to be $37{ }^{\circ} \mathrm{C}$ and 7 , respectively. $1 \%$ of glucose supplementation was found to be optimum for maximum dye decolorization by the bacterium. Cell free extracts of dye decolorization flask of Sphingomonas paucimobilis no adverse effect on Phaseolus mungo seed germination and radical and Plumule development was also enhance as compared to dye alone.
\end{abstract}

Copy Right, IJAR, 2017,. All rights reserved.

\section{Introduction:-}

Synthetic dyes are complex aromatic chemicals, designed to resist the effect of detergent, sun light and harsh temperatures ${ }^{23}$. They are chemically and photochemically very much stable and are extremely persistent in natural ecosystems. The estimated annual production of synthetic dyes has been estimated over $10^{6}$ tons worldwide ${ }^{25}$. Synthetic dyes are widely used in industries like textile, paper, food, cosmetics and pharmaceuticals with textile industry being the largest consumer'. Amongst all synthetic dyes, azo dyes are the largest group of dyes used in textile industries and are characterized by the presence of azo groups $-\mathrm{N}=\mathrm{N}-{ }^{30}$. In textile industry, during improper wet processing operations and dyeing procedures nearly 30-70 \% of the azo dyes used remain unfixed on to the textile substrate and thus finds its way into textile effluent ${ }^{18}$. This concentration reaches as high as up to 10$200 \mathrm{mg} / \mathrm{l}$ in textile effluent ${ }^{15}$. If discharged untreated into the natural ecosystem, azo dyes result in conversion of azo groups into and aromatic amines. Bioaccumulation of such products could also result in toxic effects on aquatic life and shows carcinogenic and mutagenic effects on humans ${ }^{1,29}$. 
Dyes can be removed from wastewater by a variety of physico-chemical methods such as coagulation, flocculation, reverse osmosis, oxidation and electrochemical methods ${ }^{\mathbf{1 2}, 19,20}$. These methods can only transfer dyes from one phase to another as well as are having many disadvantages like high-energy costs, high sludge production and generation of by-products ${ }^{31}$. In contrast to that, genetic diversity and metabolic versatility makes microorganisms more favorable as a biological option for the treatment of textile effluent. Fungi ${ }^{\mathbf{3}}$ and algae ${ }^{\mathbf{9}}$ uses adsorptive strategy rather than degrading dyestuff present in textile effluent. It is well known that many bacteria can degrade and completely mineralize azo dyes under certain condition $\mathbf{8 , 1 0 , 1 7 , 2 8}$. Additionally, the intermediate metabolites of decolorization process, like aromatic amines, can also be completely degraded by bacterial enzymes ${ }^{\mathbf{2 5}}$. Thus, in this study a bacterium Sphingomonas paucimobilis, capable of decolorizing Dark Red 2B azo dye was isolated and the effect of various physico-chemical parameters on dye decolorization by bacterium was investigated.

\section{Materials and Methods:-}

Soil and effluent samples were collected form chemically contaminated sites near the vicinity of Surat city. Samples were collected in sterile plastic jar and stored at $4{ }^{\circ} \mathrm{C}$ till further use. Enrichment of the collected samples was done by inoculating $1 \mathrm{ml}$ of effluent (1 mg of soil) sample in $100 \mathrm{ml}$ sterile Bushnell Hass (BH) medium (HI Media Pvt. laboratories, Mumbai) supplemented with 100 ppm of Dark Red 2B dye purchased from local textile dyes suppliers of Surat city in $250 \mathrm{ml}$ Erlenmeyer flask. Flasks were incubated at $30{ }^{\circ} \mathrm{C}$ at $100 \mathrm{RPM}$ for 2 days.

\section{Screening of Dye Decolorizing Bacterial Isolates:-}

For isolation of dye decolorizing bacteria, $0.1 \mathrm{ml}$ of enriched suspension was spreaded on $\mathrm{BH}$ agar plates supplemented with $200 \mathrm{ppm}$ dye and incubated at $30^{\circ} \mathrm{C}$ for 24 hours. Bacterial isolates having a clear zone around their colonies were taken as dye decolorizing bacteria and subjected to secondary screening. During secondary screening isolates were inoculated in $100 \mathrm{ml} \mathrm{BH}$ medium supplemented with $200 \mathrm{ppm}$ of dye. The flasks were incubated at $30{ }^{\circ} \mathrm{C}$ at 100 RPM. $5 \mathrm{ml}$ of sample was removed aseptically and centrifuged at 10,000 RPM for 10 minutes at $4{ }^{\circ} \mathrm{C}$. Decolorization efficiency was analyzed by measuring the absorbance of culture supernatant at 530 nm using UV-VIS Spectrophotometer (Shimadzu-UV-3600 Plus). The decolorizing efficiency was expressed as percentage of decolorization, which is calculated by the following formula:

\section{Percentage of Decolorization $^{6}=\underline{\text { Initial absorbance }- \text { Final Absorbance }}$ X 100 Initial absorbance}

Selected bacterial isolate was characterized on the basis of its biochemical characteristic. Biochemical tests were carried out on Phoenix Instrument, version: 6.01 A and Epi Center, version: V6.20A.

\section{Dye Decolorization Studies:-}

All the decolorization experiments were performed in triplicates. For dye decolorization, selected bacterial isolate was inoculated in $100 \mathrm{ml} \mathrm{BH}$ medium ( $\mathrm{pH} \mathrm{7)}$ supplemented with $200 \mathrm{ppm}$ of Dark Red 2B. The flasks were incubated at $30{ }^{\circ} \mathrm{C}$ on rotary shaker at 100 RPM. Samples were removed aseptically and dye decolorization was measured by the method described earlier.

\section{Effect of pH and Incubation Temperature:-}

For $\mathrm{pH}$ optimization, initial $\mathrm{pH}$ of $100 \mathrm{ml} \mathrm{BH}$ medium (with $200 \mathrm{ppm}$ of dye) was adjusted to 5, 6, 7, 8 and 9 and decolorization assay was carried out. A loop full of bacterial suspension was inoculated and incubated at $30{ }^{\circ} \mathrm{C}$ at 100 RPM. The optimal temperature for dye decolorization differs greatly from one bacterium to another. Bacterial suspension was inoculated in BH medium (with $200 \mathrm{ppm}$ of dye) and incubated at different temperatures like $30{ }^{\circ} \mathrm{C}$, $37^{\circ} \mathrm{C}, 40^{\circ} \mathrm{C}$ and $50{ }^{\circ} \mathrm{C}$ at 100 RPM. Samples were removed and checked for dye decolorization.

\section{Effect of Co-Substrates:-}

Additional co-substrates were added individually to $\mathrm{BH}$ medium like additional carbon supplementation (glucose, sucrose and maltose) at various concentrations of $0.2 \%, 0.5 \%$ and $1.0 \%$ on w/v basis. For this, $100 \mathrm{ml}$ of $\mathrm{BH}$ medium (with $200 \mathrm{ppm}$ of dye) were supplemented with different carbon sources in different concentrations, inoculated with bacterial suspension and checked for dye decolorization regularly.

\section{Effect of Dye Concentration:-}

Various dye concentrations ranging from $100 \mathrm{ppm}$ to $1000 \mathrm{ppm}$ were added to $100 \mathrm{ml}$ of $\mathrm{BH}$ medium at pH 7 in order to examine the effect of varying initial dye concentration on decolorization. 


\section{Phytotoxicity Studies ${ }^{26}$ :-}

Phytotoxicity was performed in order to assess the toxicity of the untreated and treated dye to common agricultural crops. Decolorization metabolites were extracted using ethyl acetate, air dried and dissolved in sterile distilled water. Ten seeds of Phaseolus mungo (mung) plants were sowed into a plastic petri dish with daily watering of (5 ml) of $300 \mathrm{ppm}$ dye solution (positive control) and extracted metabolites (test sample). Negative control set was carried out using distilled water (daily 5-ml watering) at the same time. Germination and length of shoot and root were recorded after 7 days.

\section{Results and Discussion:-}

\section{Isolation and Identification of Dye Degrading Bacteria:-}

The main aim of this study was to screen bacterial strains capable of decolorization and degradation of Reactive Red 2B Azo dye. Sixteen different bacterial isolates showing zone of decolorization were isolated and were subjected to secondary screening. After secondary screening, maximum dye decolorization up to $86.32 \%$ was obtained by bacterial isolate, which was identified to be Sphingomonas paucimobilis on the basis of cultural and biochemical characteristics.

\section{Dye Decolorization Studies:-}

Dye decolorization studies resulted in maximum dye decolorization up to $92.38 \%$ by Sphingomonaspaucimobilis as showed in the Figure 1.

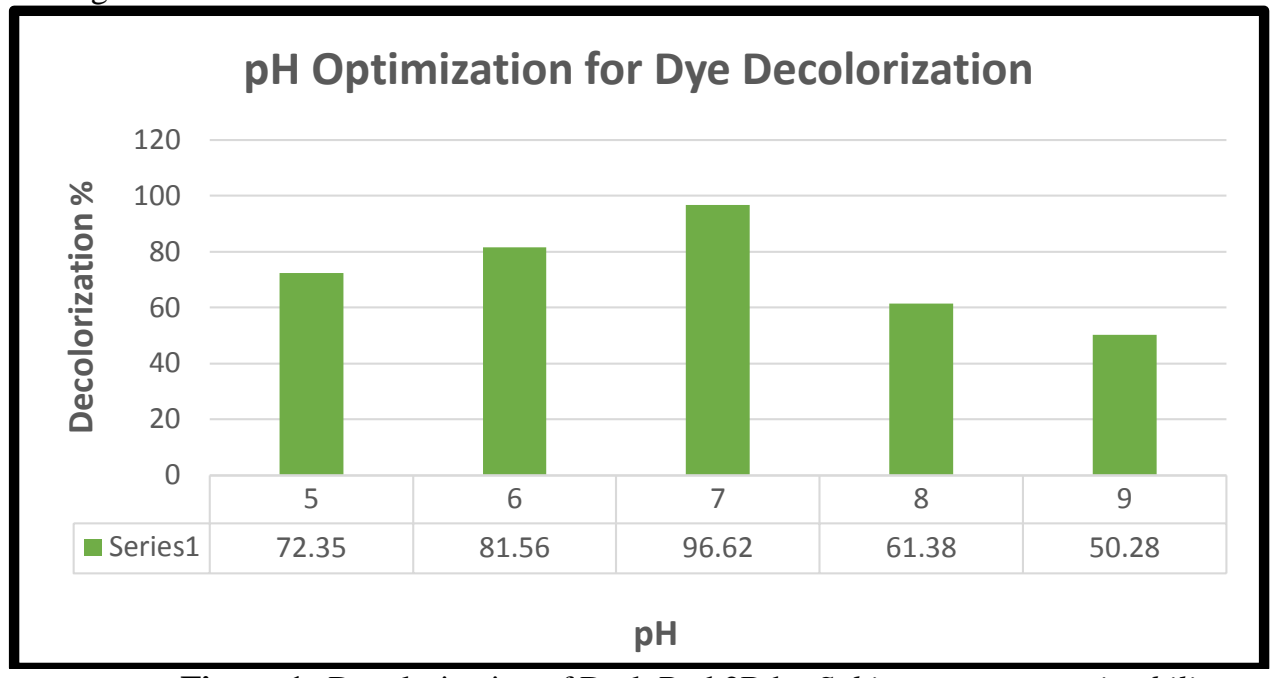

Figure 1:-Decolorization of Dark Red 2B by Sphingomonas paucimobilis.

\section{Effect of pH on Dye Decolorization:-}

It was found that change in $\mathrm{pH}$ significantly affected the rate of dye decolorization. The isolated bacterium showed maximum dye decolorization of $96.62 \%$ was obtained at $\mathrm{pH} 7$ (Figure 2) whereas the decolorization was decreased at acidic or basic $\mathrm{pH}$. Our findings were supported by other workers who also obtained maximum decolorization of Methyl Red dye at neutral pH by Bacillus species and observed Remazol Black B dye decolorization of 100\% at $\mathrm{pH}$ 7 by bacteria isolated from contaminated sites $6,1,16,21$.

\section{Effect of Temperature on Dye Decolorization:-}

The dye decolorizing potential of isolated bacterium was tested at different temperatures. Form the results it was found that the decolorization ability decreased with increase in temperature. Maximum dye decolorization of 97.35 $\%$ was obtained at $37{ }^{\circ} \mathrm{C}$ of incubation temperature (Figure 3). These findings were supported by other researchers as they observed $93 \%$ decolorization of Reactive Violet $5 \mathrm{R}$ at $37{ }^{\circ} \mathrm{C}$ by bacterial consortium JW-22. Decrease in the dye decolorization activity at higher temperature might be due to loss of cell viability or due to denaturation of enzymes responsible for decolorization ${ }^{27}$. 


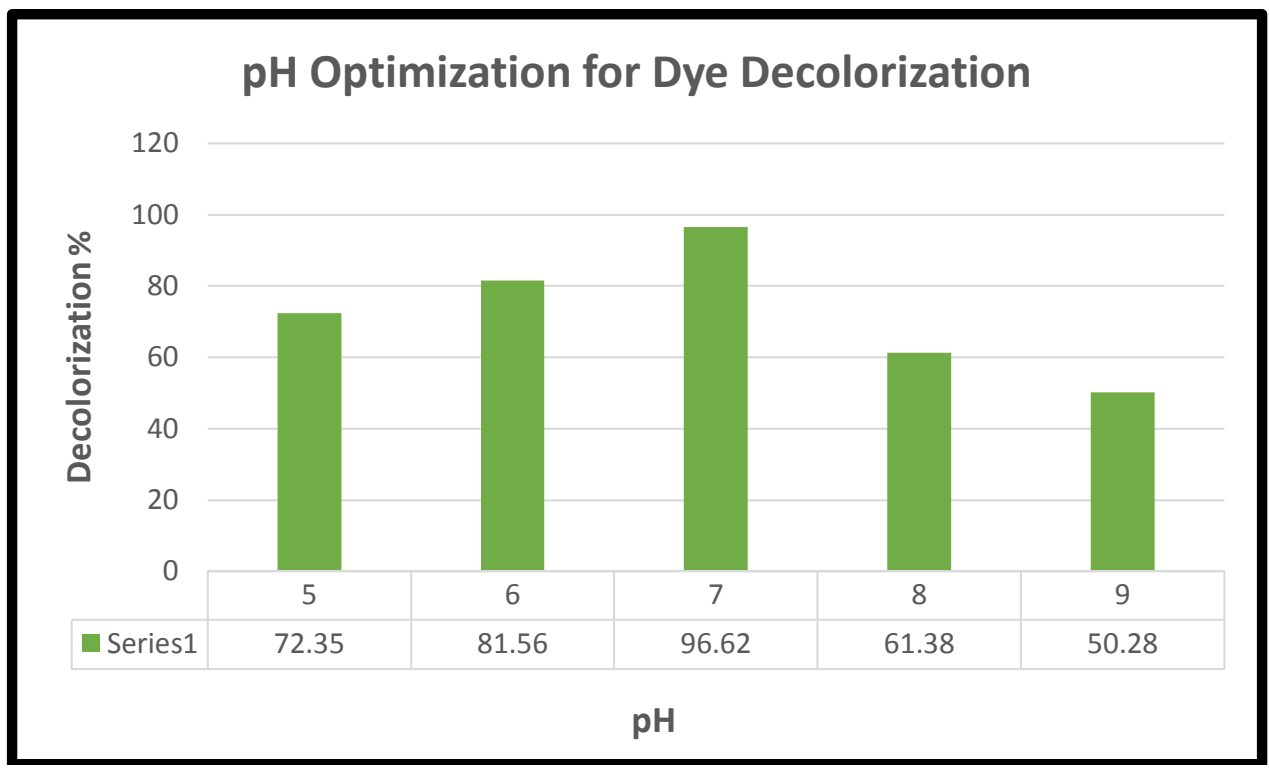

Figure 2:- pH optimization for decolorization of Dark Red 2B by Sphingomonas paucimobilis.

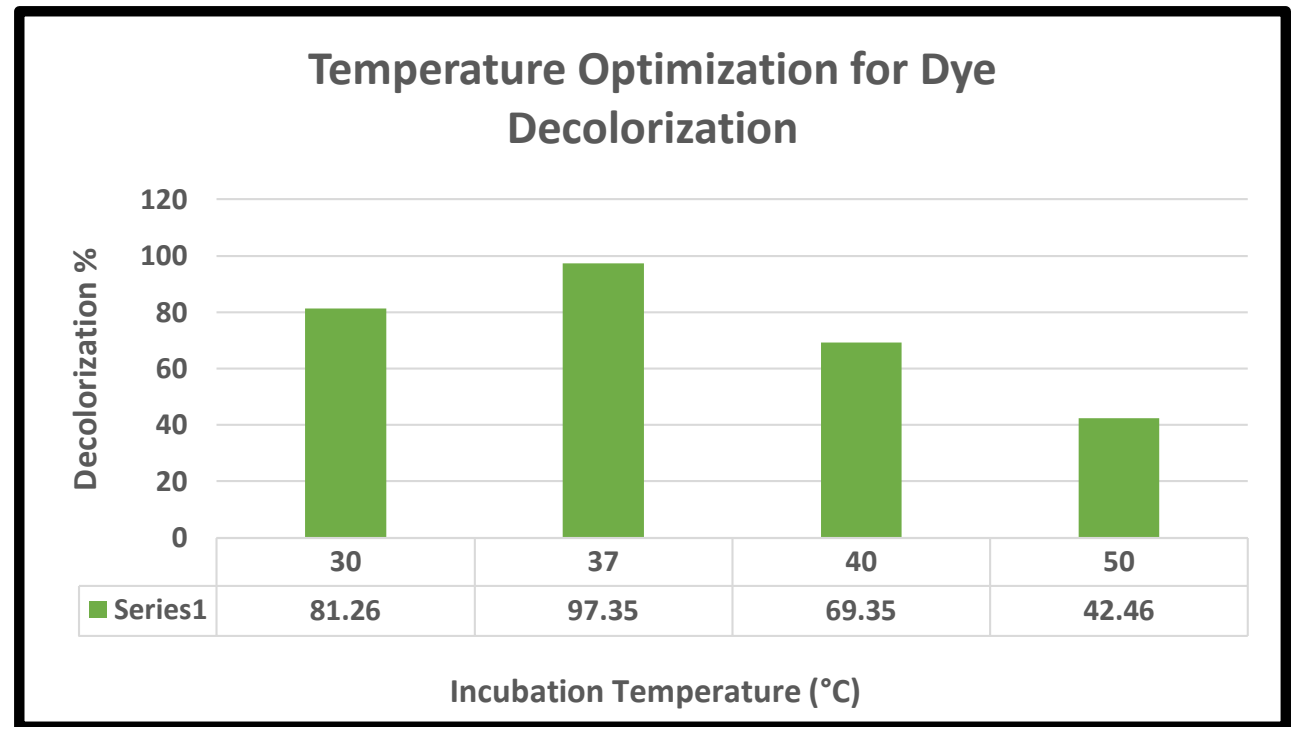

Figure 3:- Temperature optimization for decolorization of Dark Red 2B by Sphingomonas paucimobilis.

\section{Effect of Co-Substrates on Dye Decolorization:-}

Different carbon supplementation (glucose, sucrose and maltose) were used to assess their effect on decolorization. The bacterium exhibited efficient decolorization in presence of $1 \%$ glucose, whereas sucrose and maltose did not show promising effect on dye decolorization. The result of carbon supplementation study showed that maximum dye decolorization of $94.60 \%$ was obtained at $1 \%$ Glucose (Figure 4). Several reports are available for dye decolorization in presence of additional carbon source. Similar results were obtained by researchers as they obtained $90 \%$ of dye decolorization in presence of glucose as additional carbon source for decolorization of Reactive Red 180 dye by Citrobacter species $\mathrm{CK}^{32}$. In contrast other researchers found that maltose also shows stimulatory effect on dye decolorization observed that bacterial strains grew well and completely decolorized K-2BP where either yeast extract or peptone was present in the medium ${ }^{11,14}$. 


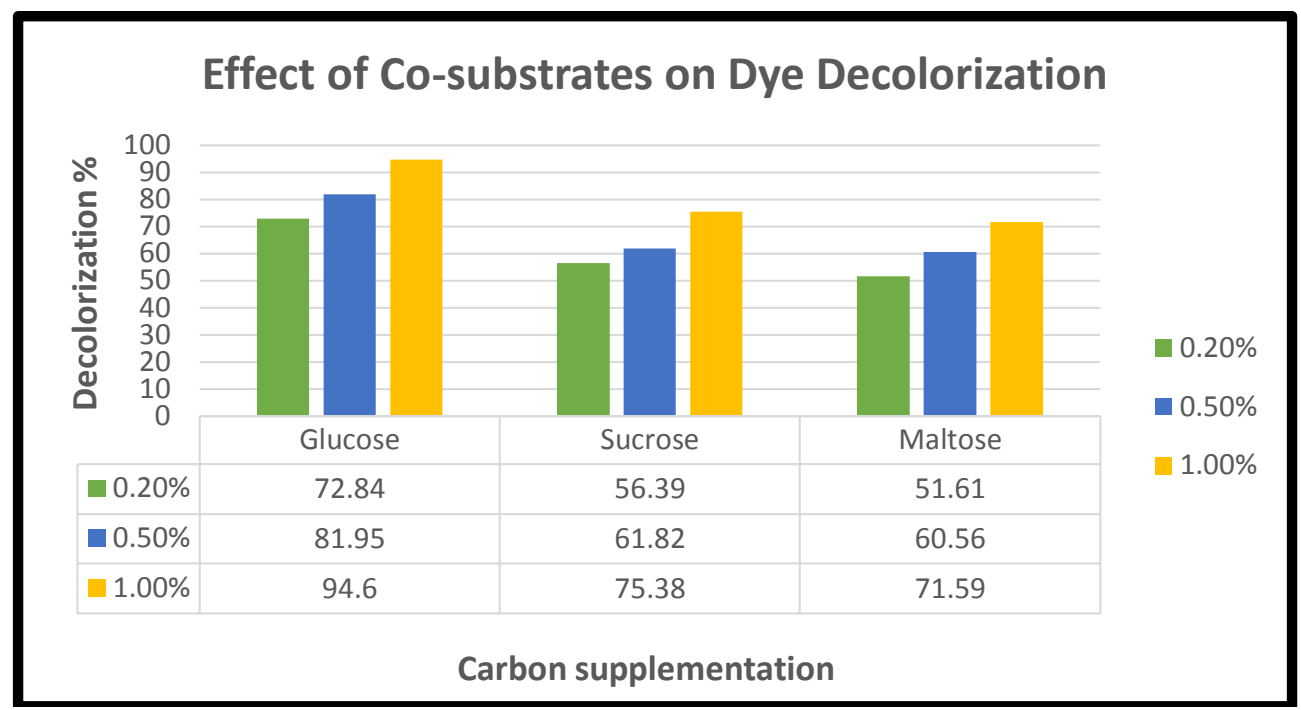

Figure 4:- Effect of co-substrates on decolorization of Dark Red 2B by Sphingomonas paucimobilis.

\section{Effect of Dye Concentration on Decolorization:-}

For this study, various dye concentrations ranging from 100 to $1000 \mathrm{ppm}$ were used along with $\mathrm{BH}$ medium. The bacterium showed decolorization at various dye concentrations but at higher dye concentrations ability of decolorization decreased as the toxicity increased (Figure 5). It has been reported that generally dye decolorization efficiency of various bacterial isolates decreases with increase in dye concentration ${ }^{26}$.

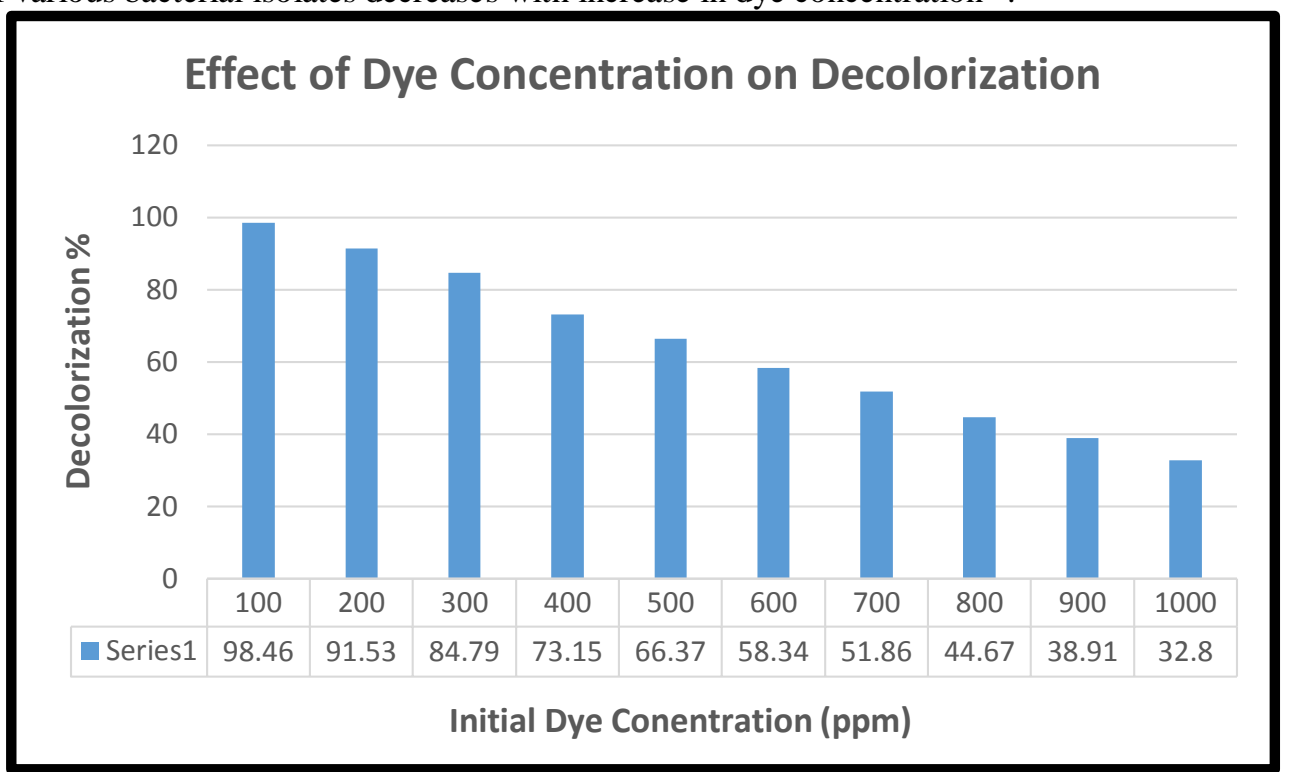

Figure 5:- Effect of initial dye concentration on decolorization of Dark Red 2B by Sphingomonaspaucimobilis

\section{Phytotoxicity:-}

Most common methods used to study phytotoxicity are monitoring of Plumule and radicle growth and assessing seed germination. The studies showed that shoot and root lengths were affected in the presence of pure dye but it was less affected when tested with extracted dye metabolites (Table1.). This indicates the detoxification of dark Red 2B dye with bacterial isolate. ${ }^{13}$ observed similar result indicating $\%$ of germination was unaffected by degraded metabolites of Dark orange 39 dye on Triticumaestivum and Phaseolus mungo seeds.

Table 1:- Phytotoxicity study of decolorization product of Dark Red 2B on Phaseolusmungo

\begin{tabular}{|c|c|c|c|}
\hline \multirow{2}{*}{$\begin{array}{c}\text { Sphingomonas } \\
\text { paucimobilis }\end{array}$} & \multicolumn{3}{|c|}{ Phaseolus mungo seeds } \\
\cline { 2 - 4 } & Water & $\mathbf{3 0 0} \mathbf{~ p p m}$ Pure Dye & Extracted Metabolites \\
\hline
\end{tabular}




\begin{tabular}{|c|c|c|c|}
\hline Germination (\%) & 100 & 40 & 100 \\
\hline Plumule (cm) & 15.8 & 6.9 & 13.9 \\
\hline Radicle (cm) & 5.6 & 2.0 & 4.6 \\
\hline
\end{tabular}

From this study it is clearly observed that the isolated bacteria Sphingomonas paucimobilis has great potential of azo dye degradation. Previously this bacterium has been investigated by many scholars for its capability of decolorization and degradation of toxic azo dyes which was observed to be $99.63 \%$ in case of Methyl Red Azo dye by this bacterium under shaking condition at $30{ }^{\circ} \mathrm{C}$ in minimal salt medium at $750 \mathrm{ppm}$ dye concentration ${ }^{5}$. Also, other researchers used Sphingomonas paucimobilis for decolorization of toxic textile dyes like Malachite green and Methylene blue $e^{4,24}$.

\section{Conclusion:-}

From this study it is concluded that bacterial isolate Sphingomonaspaucimobilis showed $98.46 \%$ of dye decolorization at $100 \mathrm{ppm}$ dye concentration. The best temperature and $\mathrm{pH}$ for decolorization of Reactive Red 2B azo dye was found to be $37{ }^{\circ} \mathrm{C}$ and 7.0 respectively. The most effective co-substrate for dye decolorization was found to be $1 \%$ glucose. The reactive Red 2B dye showed phytotoxicity against Phaseolus mungo seeds, after efficient decolorization of the dye, the degraded products obtained show less toxicity. As a conclusion, this study reports that the dye decolorization potential of Sphingomonaspaucimobilis can be exploited for bioremediation treatment of azo dyes contaminated in the industrial effluent. Thus, degraded dyes can be safely discharged into the ecosystem without harming the natural flora.

\section{Bibliography:-}

1 Acuner E and Dilek FB (2004); Treatment of tectilon yellow 2G by Chlorella vulgaris. Proc. Bioche., 39:623631.

2 Alalewi A and Jiang C (2012); Bacterial influence on textile wastewater decolorization. J. Env. Prot., 3:889903.

3 Asgher M, Kausar S, Bhatti HN, Shah SAH and Ali M (2008); Optimization of medium for decolorization of Solar golden yellow R direct textile dye by Schizophyllum commune IBL-06. Int. Biodet. Biodeg., 61:189-193.

4 Ayed L, Chaieb K, Cheref A and Bakhrouf A (2009);Biodegradation of triphenyl methane dye Malachite Green by Sphingomonaspaucimobilis. Wor. J. Micro. Biotech., 4:705-711.

5 Ayed L, Mahdhi A, Cheref A and Bakhrouf A (2011); Decolorization and degradation of methyl Red by and isolated Sphingomonaspaucimobilis: Biotoxicity and metabolite characterization. Desalination, 274(1-3):272277.

6 BhoosReddy GL (2014); Decolorization and Biodegradation of Direct Blue 2B by Mix consortia of Bacillus. J. Pharm. Biol. Sci., 9(2):34-40.

7 Chang JS, and Kuo TS (2000); Kinetics of bacterial decolorization of azo dye with Escherichia coli NO3. Biores. Tec., 75(2):107-111.

8 Chen KC, Wu JY, Liou DJ and Hwang SCJ (2003); Decolorization of the textile dyes by newly isolated bacterial strains. J. Biotech., 101:57-68.

9 Daneshvar N, Khataee AR, Rasoulifard MH and Pourhassan M (2007); Biodegradation of dye solution containing Malachite Green: optimization of effective parameters using Taguchi method. J. Hazard. Mat., 143:214-219.

10 Gudmalwar RM, and Kamble LH (2012); Biodegradation of reactive Red 4E8Y5 by using Providencia spp. RMG1 and Bacillus spp. RMG2. Sci. Res. Rep., 2(2):178-188.

11 Guo J, Zhou J, Wang D, Tian C, Wang P and Salah MU (2008); A novel moderately halophilic bacterium for decolorizing azo dye under high salt condition. Biodegradation, 19:15-19.

12 Jadhav JP, Parshetti GK, Kalme SD, Govindwar SP (2007); Decolourization of azo dye methyl Red by Saccharomyces cerevisiae MTCC 463. Chemosphere, 68:394-400.

13 Jadhav UU, Dawkar VV, Tamboli DP, Govindwar SP (2009); Purification and characterization of veratryl alcohol oxidase from Comamonas sp. UVS and its role in decolorization of textile dyes. Biotechnol. Biopro. Engg., 14:369-76.

14 Jilani K, Asgher M, Bhatti NH and Mushtaq Z (2010); Shake Flask Decolorization of Direct Dye Solar Golden Yellow R by PleurotusOstreatus. J Chem. Soc. Pakistan, 01(33):209-214. 
15 Kadam AA, Telke AA, Jagtap SS and Govindwar SP (2011); Decolorization of adsorbed textile dyes by developed consortium of Pseudomonas sp. SUK1 and Aspergillusochraceus NCIM-1146 under solid state fermentation. J. Hazard. Mater., 189:486-494.

16 Kahlid A, Mahmood S, Arshad M, Nazli ZH and Mahmood T (2011); Isolation and screening of azo dye decolorizing bacterial isolates from dye-contaminated textile wastewater. Soil Environ., 30(1):7-12.

17 Kapdan IK and Erten B (2007); Anaerobic treatment of saline wastewater by Halanaerobiumlacusrosei. Process Biochem., 42:449-453Hao OJ, Kim H and Chiang PC, 2000. Decolorization of wastewater. Criti. Rev. Environ. Sci. Tech., 30:449-505.

18 Khaled A, Nemr EA, Sikaily EA and Abdelwahab O (2009); Removal of Direct N Blue-106 from artificial textile dye effluent using activated carbon from orange peel: Adsorption isotherm and kinetic studies. J. Hazard Mater., 165:100-110.

19 Lin SH and Peng CF (1994); Treatment of textile wastewater by electrochemical method. Wat. Res., 28:277282.

20 Lin SH and Peng CF (1996); Continuous treatment of textile wastewater by combined coagulation, electrochemical oxidation and activated sludge. Wat. Res., 30:587-592.

21 Mali, PL, Mahajan MM, Patil DP and Kulkarni MV (1999); Biodecolorisation of members of triphenyl methane and azo groups of dyes. J. Sci. Ind. Res., 59:221-224.

22 Moosvi S, Kher X and Madamwar D (2007); Isolation, characterization and decolorization of textile dyes by a mixed bacterial consortium JW-2. Dye. Pig., 74:723-729.

23 Nigam P, Banat IM, Singh D and Marchant R (1996); Microbial process for the decolorization of textile effluent containing azo, diazo and reactive dyes. Process Biochem.,31:435-42.

24 Noraini C, Hasnam C, Norhashimah M, Ismail N, Tow TT and Jason OC (2012); Methylene blue degradation by Sphingomonaspaucimobilis under anaerobic conditions. Wat. Air \& Soil Pollu., 223(8):5131-5142.

25 Pandey A, Singh P and Iyengar L (2007); Bacterial decolorization and degradation of azo dyes. Int. Biodet. Biodegr., 59:73-84.

26 Parshetti G, Kamle S, Saratale G and Govindwar S (2006); Biodegradation of Malachite green by Kocuriarosea MTCC 1532. Acta. Chim. Slov., 53(4):492-498.

27 Pearce CI, Lloyd JR and Guthrie JT (2003); The removal of color from textile wastewater using whole bacterial cells: a review. Dyes and pigments, 58:179-186.

28 Prasad MP (2014); Studies on the degradation of textile dye by Pseudomonas aeruginosa. Res. J. Rec. Sci., 3:59-62.

29 Saratale RG, Saratale GD, Kalayani DC, Chang JS and Govindwar SP (2009); Enhanced decolourization and biodegradation of textile azo dye Scarlet R by using developed microbial consortium-GR. Biores. Techn., 100:2493-500.

30 Saratale RG, Saratale GD, Chang JS and Govindwar SP (2011); Bacterial decolorization and degradation of azo dyes: A review.J. Tai. Inst. Chem. Eng., 42(1):138-157.

31 Sarioglu M and Bisgin T (2007); Removal of Maxilon Yellow GL in a mixed methanogenic anaerobic culture. Dyes and Pigments, 75:544-549.

32 Wang HJ, Su JQ, Zheng XW, Tian Y, Xiong XJ and Zheng TL (2009); Bacterial decolorization and degradation of the reactive dye Reactive Red 180 by Citrobacter sp. CK3. Int. Biodet. Biodeg., 63:395-399. 